\title{
Migrants and Low-Paid Employment in British Workplaces
}

Alex Bryson (University College London). Corresponding author: Alex Bryson, UCL, Department of Social Science, 20 Bedford Way, London, WC1H 0AL a.bryson@ucl.ac.uk

Michael White (University of Westminster)

\begin{abstract}
Using nationally representative workplace data for Britain we identify where migrants work and examine the partial correlation between workplace wages and whether migrants are employed at a workplace. Three-in-ten workplaces with 5 or more employees employ migrant workers, with the probability rising substantially with workplace size. We find the bottom quartile of the log earnings distribution is 4-5 percent lower in workplaces employing migrants, ceteris paribus. However, the effect is confined to workplaces set up before the introduction of the National Minimum Wage (NMW) in the late 1990s, consistent with the proposition that minimum wage regulation limits employers' propensity to pay low-wages in the presence of migrant workers.

Key words: migrants; migration; wages, earnings; low pay; minimum wage; discrimination.

Acknowledgements: The authors acknowledge the Department for Business, Energy and Industrial Strategy, the Economic and Social Research Council, the Advisory, Conciliation and Arbitration Service and the National Institute of Economic and Social Research as the originators of the Workplace Employee Relations Survey data, and the Data Archive at the University of Essex as the distributor of the data.
\end{abstract}




\section{Introduction}

Like many parts of the European Union, Britain has experienced substantial in-migration in the last few decades, in part due to the free movement of labour associated with the Single European Market and, more recently, to the influx of refugees and economic migrants fleeing conflict and disadvantage in Africa, the Middle East and parts of Asia. As a result, the age and ethnic complexion of the British population has been changing. The share of immigrants among working age adults in the UK more than doubled between 1995 and 2014 - from 8\% to 17\% and now stands at over 6.5 million (Wadsworth, 2015). These changes have occasioned political debate regarding immigration policy, the resource implications for the State, and British identity which culminated in the Brexit vote in June 2016's referendum.

The labour market implications of immigration are hotly contested. On the one hand, there is a general recognition that parts of the economy would be unable to function efficiently without substantial reliance on migrant labour. They include sectors as diverse as the National Health Service, fruit picking and construction. ${ }^{i}$ On the other hand, concerns have been expressed about the potential impact immigration may have on unemployment among native-born working age people and ambient wages, particularly at the lower end of the labour market. As we discuss in Section Two, there is little empirical evidence that immigration has had adverse consequences for the employment prospects of native workers in Britain, and adverse wage effects are not discernible.

We contribute to the literature on migration by focusing on what has been happening at workplace level and at the low pay margin. Information of this type is available in the Workplace Employment Relations Survey 2011. Using these data, we identify which workplaces employ migrants and, using a matching estimator, consider whether workplaces employing migrants pay lower wages than otherwise similar workplaces that do not employ migrants. By comparing workplaces that were established before and after the introduction of the National Minimum Wage (NMW) we test the proposition that wage regulation can limit any migrant effect on workplaces paying low wages. 
To provide a conceptual platform for our inquiry into these issues, we contrast neoclassical ideas that assume competitive processes rapidly smooth out pay distortions arising from migrant inflows, with an imperfect-competition, monopsony view of low-pay bargaining. An implication of the latter view is the persistence of wage distortions.

The paper's contribution to the literature is three-fold. First, we show that, while some workplaces that employ migrants are concentrated in low-paying segments of the economy such as hospitality, migrants are also found in higher-paying workplaces experiencing upward pressure on pay, either for locational reasons (London and the South East), or because of their large size or skilled workforce. Second, we confirm claims that the employment of migrants reduces pay levels at the lower margin. Third, we show these wage effects are largely absent in workplaces set up after the introduction of the NMW compared to effects in workplaces set up prior to the introduction of the NMW, supporting the proposition that wage regulation can limit migrant effects in lowering wages. This last finding is particularly relevant to current policy debates concerning pay regulation, including the potential impact of the new National Living Wage.

The next section considers potential reasons for an association between migrants and low pay and reviews recent research on migrants and pay in Britain. This is followed by a section outlining our theoretical approach and its implications for migrant wage effects. Two subsequent sections describe the analysis plan, and the results. Conclusions are summarized, and policy implications discussed, in the final section.

\section{Theory and previous research on migrants' effect on pay}

There are many reasons why there might be an association between the employment of migrants and the incidence of low pay at a workplace. First, if migrants have lower wage-enhancing attributes than native workers, such as qualifications or labour market experience, this will be reflected in lower earnings. If this is the sole reason for a differential then conditioning on the occupational composition of workers, their workplace tenure, and other human capital attributes would close the differential. ${ }^{\text {ii }}$ 
Second, where migrants are observationally equivalent to native workers they may be direct substitutes for native workers, in which case they may be in direct competition with them in the labour market. This may strengthen the bargaining hand of employers in setting lower wages than they might otherwise have done in the absence of migrant competition for jobs. In the longer run, in an efficient labour market, those migrants who were initially low paid may acquire human capital and improve their earnings, and the dynamic effects of their absorption into the labour market may have positive effects on employment and earnings. However, if one assumes a relatively fixed demand for labour in the short-run, an increase in labour supply through migrants will shift equilibrium wages downwards. ${ }^{\text {iii }}$

Third, migrants may be unable to procure the market wage merited by their human capital if they face difficulties using their skills in the host country. This may be because they lack the language skills necessary to take up the profession they had in their native country, the host country fails to recognize the qualifications they possess or requires them to retrain in full or in part, or because they face employer discrimination. Employers may discriminate against migrants by refusing to employ them or, having done so, by paying them lower wages than their skills and experience merit, or lower than the wages they pay similar native workers. Discrimination may be statistical in the sense that employers make judgments about classes of worker based on observable attributes, such as language or race, it may arise where employers succumb to pressure from customers or co-workers to discriminate, or it may reflect taste-based discrimination in which employers have a preference for native workers which they pursue in their employment practices, even if this comes at the price of failing to recruit or reward the most productive workers. ${ }^{\text {iv }}$

Fourth, since migration to Britain has been substantial over many years its effects may have important implications for the operation of the whole labour market. Migrants may have spillover effects on the way the rest of the economy works, so that standard partial equilibrium assumptions regarding labour market "treatments" do not hold. For instance, native workers may respond to increased migrant competition by shifting to other locales or occupations where they do not face the same level of competition. They may even become economically inactive, raising questions as to whether migrants increase the potential supply of labour. In turn, 
employers may respond to the decline in labour supply by native workers for a given type of job by seeking migrant workers instead. ${ }^{\mathrm{v}}$

As noted by Ruhs and Vargas-Silva (2014) in their review of the literature, the wage effects of immigration will depend on the skills of migrants, the skills of natives, and specific labour market and institutional conditions. As such "research evidence on the labour market effects of immigration is thus always specific to time and place". We focus, therefore, on the empirical literature pertaining to the UK.

The empirical literature on the impacts of immigration on native and migrant workers in the UK is mixed. The proportion of immigrants who are highly educated is higher in the UK than it is for any other European country (Alfano et al., 2016: 60). This is reflected in the higher average weekly earnings for immigrants compared with natives in 2015 ( $£ 490$ against $£ 478$ ) (op. cit.: 63). Nevertheless, Wadsworth (2015) shows immigrants are over-represented among the very high skilled and the very low skilled workers in the economy. They are most highly overrepresented in Processing and Elementary occupations (op. cit.: 6) and in the Hotels and Restaurants sector, which is where low-pay is particularly prevalent. Alfano et al. (2016: 67) suggest this was due to migrants" "occupational downgrading".

Using the United Kingdom Labour Force Survey (LFS) for 2000 to 2007, Clark and Drinkwater (2008) find migrants did worse than native born workers in terms of both employment rates and earnings. Dustmann et al. (2005) find no significant employment impact of immigration over the period 1983-2000. Wadsworth (2015) finds no association between growth in immigration at county-level and unemployment and NEET rates for native youths living in those areas, suggesting they are not substituting for one another in the labour market.

Turning to wages, using LFS and General Household Survey (GHS) data for 1973-2007 Manacorda et al. (2012) find no significant effect of migrants on native workers' wages due to imperfect substitution. However, they find immigration has a sizeable negative effect on existing immigrants' earnings. Dustmann et al. (2013), on the other hand, finds a small negative effect of migrants on the earnings growth of those in the bottom quartile of the earnings distribution over the period 1997-2005, but a positive effect higher up the earnings distribution 
(Dustmann et al., 2013). They also present evidence that immigrants tend to be better qualified than natives but suffer a wage penalty on arriving in the UK due to occupational downgrading, but that penalty disappears as migrants move up the earnings distribution through occupational moves and promotions.

The empirical literature is dominated by the analysis of household survey data. Because these data are unable to locate migrant and native workers within and across workplaces, it is limited in what it can say about the demand side of the labour market and the potential effects of migrants on workplace wage setting. To our knowledge, there is only one study for Britain using workplace-level data to examine the links between migration and wages. It finds the employment of migrant workers had no significant impact on employer responses to the recession, either in terms of cuts to wage and non-wage benefits or wage freezes (Bryson and Forth, 2016). However, the probability of a pay freeze or cut for the largest non-managerial occupational group in the last pay settlement rose with the proportion of non-EEA nationals employed by the workplace (op. cit.). One-quarter (26 per cent) of private sector workplaces had instituted a pay freeze or cut for the largest non-managerial group of employees in the last pay settlement. An increase of one percentage point in the number of non-EEA nationals employed at a workplace raised the probability of a wage freeze or cut by roughly 0.4 of a percentage point. The proportion of EEA nationals was not statistically significant. The authors suggest: "One potential explanation for this finding is that a workplace's ability to employ non-EEA nationals reduces the bargaining power of employees at that workplace, thus limiting employees' ability to resist wage freezes or cuts" (Bryson and Forth, 2016: 161).

In summary, the empirical evidence for Britain suggests migrants have more substantial wage and employment effects on earlier migrants than they do on the native population. However, there is some indication that migrants affect earnings at the lower part of the wage distribution due, in part, to occupational downgrading by migrants on first arriving in Britain.

\section{Low pay at the workplace}

The intensification of competition and the resulting financial pressures that have been associated with globalization (Beck, 2000; Dreher et al., 2008) and the advent of the 'service economy 
model' (Castells, 2000) have fashioned an economy in which employers pay high wages where they must (e.g., managers and 'core' employees) and pay low where they can (e.g., Kalleberg, 2011). Assuming employers act rationally in their own interests (Goldthorpe, 2007), and that private sector firms are profit-maximising, the increase in migrant labour supply to the UK described above provided an opportunity for employers to restrain labour costs.

To conceptualize a link between the employment of migrants and low pay, we draw upon the theory of monopsonistic power/exploitation developed by Joan Robinson in the 1930s (Robinson, 1933) and applied in recent years by both economists and sociologists. Monopsonistic power consists in the ability of an employer to pay employees a wage that is below the competitive market wage, despite itself having competitors. As expressed by Ashenfelter et al. (2010: 3), '...the employer with monopsony power will hire less labor and pay lower wages than the otherwise equivalent employer in a competitive labor market.'

In some cases, monopsonistic power arises because an employer achieves a dominant position in a particular section of the labour market (Neumark et al., 2005). More commonly, monopsonistic power arises from the weakness of employees and job-seekers relative to employers. Disadvantages faced by individuals include costs of and restrictions on job search and mobility, and lack of information about what the employer is willing to pay, or more generally about opportunities in the labour market. The idea that monopsony can play an important role in determining worker outcomes is used by Gangopadhay and Shankar (2015) who examined worker exploitation in an informal urban setting in Bangladesh. They argue that the institutionally and socially 'tied' nature of informal workers helps explain their exploitation. Schmid (2016) uses monopsony power as one of several concepts to explain the persistence of gender discrimination in Switzerland, stressing women's lack of mobility, compared with men, as a factor in their low pay.

We argue that migrant flows to the UK might provide employers with market power to set lower wages for migrants and non-migrants alike, consistent with a monopsony view of the operation of the labour market. Under the competing neo-classical model of the labour market, the arrival of job-seeking migrants is an external shock to the labour market which increases labour supply, resulting in a downward adjustment in wages. However, as the market is competitive and fully- 
informed, adjustment takes place smoothly through labour mobility and competition for workers. In contrast, under the monopsony model, competition in the labour market is limited because actors have imperfect information. Migrants may be disadvantaged in the labour market for multiple reasons. For example, they may be dependent on 'sponsoring' employers, or have been recruited remotely by agents of the employer rather than directly; and they may lack knowledge relating to language, social custom and practice, prevalent wage rates and so on. At the same time, competition between employers may be limited or fragmented because some employers are better positioned than others to be sought out by migrants, for instance because of their locational advantages, their prominence (size, recruitment resources), or history. These advantages can be the basis for employer monopsony power, as illustrated in several previous studies (e.g., localized recruitment of teachers, Ransom and Sims, 2010). ${ }^{\mathrm{vi}}$ In these circumstances employers can recruit migrants at lower pay than the going rate while also holding down pay for existing employees through the implicit threat of replacing them. The bargaining power of newly recruited migrants is limited by their lack of knowledge, by insider-outsider pressures, and by short tenures creating a disincentive to joining a union. This situation, which is favourable to employers, can persist, once established, as a result of continual migrant turnover and because new recruits keep flowing along the established channels.

Because of employees' weak position, monopsonistic power is probably very widespread (Ashenfelter et al., 2010: 9). It even applies in the small firm sector, as illustrated in research on wage setting at the time of introduction of the NMW (Gilman et al., 2002). These authors concluded that "we have produced evidence consistent with monopsony arguments, notably the restricted labour market choices of employees in restaurants' (Gilman et al., 2002:65). Alongside insightful sociological studies, one can set robust econometric evidence of the wide extent of monopsonistic exploitation. Notably, Benmelech et al. (2018) have used large-sample data to demonstrate the relationship between local labour market/industry concentration and lowered wage shares across USA manufacturing industry over several decades.

\section{Migrants and low wages before and after the NMW}

Ashenfelter et al. (2010) describe minimum wage legislation as a 'textbook remedy' for monopsonistic exploitation. There is very strong evidence, summarized by Metcalf (2007), that 
the NMW has achieved a significant reduction in low wages and in wage inequality without adverse effects on employment (Metcalf 2007: 59). This is consistent with the imperfect competition and monopsony wage setting view of the labour market (Robinson, 1969: 295). Metcalf (2007: 25-28) points out that in the UK labour market it would be very easy for employers to breach the NMW with little risk of punishment. Yet it appears that such breaches have been infrequent. Further, there are indications that the introduction of a NMW alters social norms with respect to pay in a way that counters exploitation by employers (Falk et al. 2006). For migrants, the NMW provides an anchor point from which they can assess wage offers. For these reasons, we anticipate that workplaces 'born' in the NMW era will adopt policies and practices that, in large part, conform to the requirements of the NMW, thus limiting the ability of employers to downwardly adjust workplace wages via the employment of migrant labour.

New requirements to pay a NMW may operate somewhat differently in older workplaces set up prior to its introduction. These employers have pre-existing wage structures and procedures that need to be adapted to new regulations. However, they may be constrained in their ability to adapt them due to the costs of replacing or amending current systems (costs which do not apply to employers starting afresh in the NMW era) and by limited knowledge about their new responsibilities. This is precisely the scenario uncovered by Gilman et al. (2002) in their study of small firms. They noted workers often had limited knowledge of and ability to engage in the labour market; relevant factors included lack of English-speaking competence among ethnic minority workers, experience confined to one industry, and few external contacts. They thus 'can become locked into a sector and accept pay below the National Minimum Wage' (Gilman et al., 2002: 62). The small firms in this research did not fully exploit their advantage, in part because of the particularism of their wage setting and also in response to the pressure of social norms. Nevertheless, the idea that workers can be 'locked in' to low wages in monopsonistic markets, and that firms can be 'locked in' to recruitment and wage determination procedures offering very low wages, suggests that older workplaces - even larger ones - who have set up a low-wage structure exploiting monopsony power may find it very costly to deviate from it, not least because raising the wage for any low-paid group may have 'spillover' implications for pay in other parts of the structure. ${ }^{\text {vii }}$ These indirect effects are potentially far more expensive than the direct ones (Ashenfelter et al., 2010). Thus, even where firms experience pressure for pay 
equalization, they may respond only partially. An outstanding case is gender inequality, that was certainly reduced by the NMW (Metcalf, 2007), yet remains substantial and almost universal in British employment.

The implication from the discussion above is that, whereas new workplaces born in the NMW era face a wage floor limiting the power of migrant labour to lower workplace wages, older workplaces with pre-existing arrangements to recruit and pay migrant labour will only partially adjust to the new NMW regime, such that migrant labour will continue to have some impact in lowering workplace wages.

\section{The research: data, variables, analysis}

\section{The dataset}

We used the 2011 Workplace Employment Relations Study (WERS11). This national sample survey covers British workplaces with at least 5 employees (van Wanrooy et al., 2013), excluding only agriculture and mining. Our analysis used the data from personal interviews with a senior employment relations/human resources manager. The sample size for analysis after eliminating cases with inconsistent or missing data was between 2113 and 2119 workplaces.

The WERS 2011 had a response rate of 46 per cent. The public use survey weights restore the representativeness of the survey to national distributions by size and industry. We address sample selectivity in our methodology by using a covariate balancing approach that ensures workplaces not employing migrants are closely matched to employers of migrants on all the variables we judge to be relevant. The remaining issue is whether the sub-sample of employers of migrants is itself skewed by sample selectivity. In the absence of national benchmark data for workplace employment of migrants, it is impossible to resolve this question.

\section{The measure of low wages}

The management respondents were asked to break down their total employment into six wagebands, starting at the bottom end with those paid at the NMW (£5.93/hour) or below. (See Table 1 for the pay bands.) Where the total pay band numbers differed from total employee headcount 
by plus or minus 10 per cent or more, the observation was discarded, leading to a loss of six per cent of the data. In addition, 36 cases were adjusted to eliminate a smaller discrepancy.

The survey questioning did not specify a lowest or a highest wage paid. To close the distribution, we used $£ 5.00$ as a lower bound and $£ 30.00$ as an upper bound. Exploratory analyses with different upper and lower bounds indicated that results were not sensitive to this choice.

The summary measure we used was the workplace lower quartile wage, derived by linear interpolation from the wage distribution. In analysis, we used the logarithm of this number. We chose the lower quartile because policy debate is focused on low pay, rather than average pay. An employer can reduce the lower quartile wage either by increasing the number of jobs below it, or by compressing pay downward. For descriptive statistics, see Table 1, panel (a). Also shown in Table 1 (panel b) is the distribution of lower quartile points across the questionnaire pay bands. This shows that the most common position for the lower quartile point was in the $£ 7.51$ to $£ 10.0$ pay band -30 percent of workplaces fell within this band.

Two points about our low pay measure should be noted. It addresses low pay for all types of employees, rather than low pay for migrants; there may be some presumption that if migrant employment is linked to low pay, then the migrants themselves tend to be low-paid, but this does not follow, since migrant employment may also influence the pay of native workers. Further, the low pay measure does not directly address pay at or below the NMW, it covers a considerably wider band of low pay, as shown in Table 1.

\section{[INSERT TABLE 1]}

\section{Explanatory variables - migrant employment, workplace age}

The chief explanatory variable is a dichotomy dividing workplaces that employed any migrant workers at the time of the survey (scored ' 1 '), from those that had no migrant workers (scored ' 0 '); we call these 'migrant' and 'no migrant' workplaces. This variable is derived from 
questions that ask employers to provide the number of non-UK-citizen employees from EEA and non-EEA countries. After preliminary work in which we used the numerical data and the dichotomous variable in parallel, we concluded that the former contained substantial error variation leading to under-estimation of the migrant effect. The dichotomous variable is robust to this type of error (Kennedy, 2003). While the distinction between EEA and non-EEA employees is potentially interesting, we again judged that the numbers provided by management could often be erroneous since there is no statutory obligation to keep such data and personal perceptions may be distorted. viii Thus, our dummy variable reflects non-zero values under either category.

Our secondary explanatory variable is based on the founding date of the workplace (inclusive of time at other locations before moving to the present one) and distinguishes two groups, 'older' and 'newer' workplaces. Older workplaces are those established before 1997 while newer workplaces are those established from 1997 to 2011 inclusive. The influence of the NMW is assumed to begin in 1997, the year of the first report of the Low Pay Commission (LPC). ${ }^{\text {ix }}$ In robustness tests we ran a variant in which the cut-off year was 1999, the year when the NMW came into force, instead of $1997 .{ }^{\mathrm{x}}$

\section{Control variables}

Control variables were those usually associated with variation in wages that are also likely to be linked to migrant employment. We therefore included the percentage of employees who were female; the percentages falling into three broad occupational class or skill groups (lower-skilled, intermediate, and higher); and the percentage of employees who were on temporary contracts or were agency workers. A dummy variable captured the presence of a trade union recognized for bargaining purposes. To control for workplace size, we used the log of total number employed. A four-category variable identified the total number of employees in multi-site parent organizations, with the reference category being single-site organization. Eleven dummy variables identified the region where the workplace was located while twelve industry dummies captured its activities. A dummy variable distinguished private sector from public sector 
employers, and another identified foreign-owned firms. A table of the descriptive statistics for these variables is not shown but is available on request.

\section{Analysis methods}

The analysis had two main stages. The first stage examines the workplace characteristics associated with migrant employment. The second stage estimates the 'migrant wage effect', meaning the difference in log lower quartile wage between migrant-employing and no-migrant workplaces conditional on the control variables.

For the first stage we used a logit model with migrant employment as the outcome and the full set of control variables as the predictors. Data were weighted using the public use survey weights, and a robust variance estimator was used to compute standard errors. We also ran separate analyses for the 'newer' and 'older' workplaces to check whether there was change in the workplace characteristics influencing migrant employment after the introduction of the NMW.

For the second stage analysis, the estimation strategy consisted of data matching followed by regression on the pre-matched data (Imbens and Wooldridge, 2009). From a statistical viewpoint, pre-matching of no-migrant to migrant workplaces reduces variation and renders the subsequent regression estimates more precise. From the viewpoint of causal inference, matching is analogous to an experimental method provided that all variables that differentiate the 'treated' and 'control' groups (i.e., the migrant and no migrant workplaces), with respect to low pay, are included in the match. In practice this condition is unlikely to be met in observational data and one must make a judgement as to how close the choice of control variables comes to the ideal. Evidence on this issue is provided by the first stage results.

Matching was pursued via the entropy balancing method (Hainmueller and $\mathrm{Xu}, 2013$ ) which computes weights such that there is complete mean covariate balance between the treated and non-treated (migrant, no migrant) groups. The use of this method reflects the emphasis placed in evaluation studies on reduction of mean covariate bias as a criterion of successful matching. Whereas the more familiar propensity score matching (PSM) method typically achieves around 
60-70 per cent reduction in mean bias between treated and control groups, the entropy balancing method guarantees virtually 100 per cent reduction.

Following the covariate balancing, robust regression analysis (Berk, 1990) was carried out using the balancing weights. All control variables were used in this analysis as well as the explanatory variables. The inclusion of control variables in the regression, as well as in the prior balancing, serves to increase precision.

\section{Results}

\subsection{Descriptive background}

Some preliminary points of a descriptive type are worth noting. On an unweighted basis, there was a nearly 50-50 sample split between the migrant and no-migrant workplaces. However, reweighting the sample by the survey weights (table not shown), the proportion of migrant workplaces fell to 29 per cent, with 25 per cent of older workplaces and 32 per cent of newer being in this group. This shift occurred because the survey over-sampled large workplaces, and as the next section will show, size was strongly related to migrant employment.

We broke down descriptive information about the mean lower quartile wage by whether the workplace employed migrants. At a purely descriptive level the migrant workplaces on average had wages that were somewhat higher than the no migrant workplaces. This, however, was without controlling for the other characteristics and circumstances associated with employment of migrants.

\subsection{Characteristics of workplaces employing migrants}

The logit analyses showed that migrant employment was strongly associated with three workplaces characteristics: size, regional location, and industry. Because the logit estimates are not easily interpreted in a quantitative sense, we have relegated the detailed estimates from these analyses to Appendix Table 1. Here we focus on the derived marginal probabilities of being an employer of migrants, shown in Table 2, for each of these workplace attributes in turn. Note 
that as the logit model is non-linear, the marginal probabilities may differ from the logit estimates for particular combinations of covariate values. The marginal probabilities were here calculated while holding all other covariates at their observed values.

The most striking results were those relating to size (Table 2, panel a), with large workplaces very much more likely to employ migrants than smaller workplaces. In further analysis, we found that large workplaces not only had a high probability of employing some migrants, they tended to employ many migrants. To show this we had to resort to the management information about migrant numbers that we believe to be noisy (see earlier remarks). Even so, there can be

little doubt that migrant workers formed a sizeable part of the workforce in most large British workplaces. In workplaces that employed any migrants and had 2000-plus employees, on average migrants constituted 22 per cent of their total headcount. For those with 1000-1999 employees, this percentage fell a little to 19 per cent. As these workplaces' probability of being migrant employers is so high, it is reasonable to estimate that one in five of their employees was a migrant worker. This is consistent with employers exercising some monopsonistic power with respect to migrant workers. Large employers have the resources to organize and pay for recruitment overseas or target EEA migrants that have come to Britain as job seekers (CIPD, 2013). They also have a social prominence and reputational assets that simplify job search for migrant job-seekers.

\section{[INSERT TABLE 2]}

Table 2 (panel b) shows that migrant employers were particularly concentrated in London and South-East, the South-West, and to a lesser extent in East Anglia and the Midlands. One in two of newer workplaces in London and the South-East were migrant employers. Migrants act rationally in searching areas where the general level of wages is relatively high, hoping in this way to partially offset monopsonistic exploitation.

Among industries (Table 2 panel c) the leading employer of migrants was hospitality, with a migrant probability of 0.52 . Second came health services with a probability of 0.38 . Other industries with probabilities in the range 0.25-0.30 were manufacturing, distribution, and business services - the three industries with the largest private sector employment in the British 
economy. The prominence of hospitality and health as employers of migrants reflects long established recruitment traditions in these industries. Previously constructed links to particular overseas sources of skilled labour facilitate matching of employers to overseas job seekers and enable monpsonistic exploitation.

\section{3: Workplace low wage effect of employing migrants}

The second stage of analysis was conducted with full controls for both the entropy balancing procedure and the subsequent regression analysis using the balancing weights. The regression for the full sample was run with two specifications in the explanatory variables. Model 1 introduced migrant workers and newer workplaces separately to identify additive effects. Model 2 interacted the two terms. In addition, analyses were run separately for the pre-NMW (model 3) and post-NMW (model 4) subsamples, including separate balancing before regression with migrant employment as the sole explanatory variable. Models 3 and 4 together are another way of obtaining the interaction effect of Model 2 but differ from Model 2 in permitting the covariance structure to differ between the subsamples.

Bias reduction in the balancing procedure was virtually 100 per cent (convergence is achieved when all covariate mean differences are less than 0.003). The regression results for the explanatory variables are summarized in Table 3. For reasons of space, the results for the entropy balancing and for the control variables in the regression analysis are not shown, but are available on request.

In the whole sample employing migrants resulted in an average reduction of the lower quartile wage by about 4.5 per cent, significant at the 5 per cent level. Newer workplaces had a slightly higher lower quartile wage (conditional on the controls) but this main effect was non-significant. However the interaction of migrant employment with workplace age in Model 2 indicates that the migrant effect on low pay is concentrated in older workplaces, where the reduction is estimated at 5 per cent, while for newer workplaces the effect is near zero. Overall, then, there is a significant interaction effect. This picture is confirmed by the analyses of separate subsamples (Models 3 and 4); these yield a slightly larger negative effect (-6 per cent) across the older workplaces, while the effect for newer workplaces remains near zero. Note, however, that 
comparison of estimates between the newer and older sub-samples is non-rigorous, because each estimate is based on a separate covariate rebalancing procedure. The more conservative estimates of Model 2 have the advantage of directly testing the migrant $\mathrm{x}$ workplace age interaction, whereas Models 3 and 4 benefit from permitting the covariance structures to vary between subsamples in a flexible way. That both methods lead to similar conclusions provides a form of constructive validation (Treadway et al., 2005).

\section{[INSERT TABLE 3]}

\section{Robustness assessment}

We conducted several further checks on robustness, using the simplest model (Model 1) as the starting point for comparisons. Bias resulting from omitted (unobserved) variables constitutes a serious threat to the validity of estimated effects. Altonji et al. (2005) suggest that a useful means of assessing such bias is to compare estimates between specifications with and without controls. The rationale is that the controls are selected on the basis of experience so as to minimize bias, so deliberately omitting them exposes the estimates to severe bias. If the estimates remain reasonably stable they are unlikely to be much affected by omission of (probably) much weaker variables. Retaining the balancing procedure, but omitting all controls from the regression, we obtained an identical estimate for the effect of migrant employment (a fall in the lower quartile wage of 4.5 per cent), while the R-squared fell from 0.675 to 0.04 , indicating the strength of the controls. This information constitutes strong evidence of robustness to omitted variable bias.

Other robustness tests concerned particular details of the variable specification. We changed the definition of older/newer workplaces by moving the dividing date to 1999 instead of 1997. Estimates for model 1 were unaffected. We also investigated sensitivity of estimates to the presence of extremely low values of the weighting variable generated by the entropy balancing procedure. After balancing we removed cases in the first percentile of weights (22 cases) before performing the regression analysis. Results were again unaffected, suggesting that the entropy balancing method is rather insensitive to this type of problem. 


\section{Conclusion}

Our study is, to our knowledge, the first to use nationally representative workplace data for Britain to identify where migrants work and the partial correlation between the incidence of migrants and the probability of a workplace paying low wages. Three-in-ten (29\%) of workplaces with 5 or more employees employ migrant workers. The probability of employing migrants rises with the size of workplace (as does the percentage of workers who are migrants). They are geographically concentrated in London and the South East, and the South West of England, and in certain industries, notably hospitality. Unlike other studies, we do not directly compare the wages of migrant workers with native workers, nor recover the direct spillover effect of migrant on native wages. Instead, we identify the partial correlation between the log lower quartile workplace wage and the presence of migrants. We recover this for periods preand post the introduction of the National Minimum Wage to test the hypothesis that minimum wage regulation challenges the monopsony wage setting power of employers who might otherwise pay low wages to migrants. We find the bottom quartile of the log earnings distribution is $4-5 \%$ lower in workplaces employing migrants, ceteris paribus. However, the effect is confined to workplaces set up before the introduction of the NMW in the late 1990s, consistent with the proposition that minimum wage regulation limits employers' propensity to pay low-wages in the presence of migrant workers. The implication is that policy interventions such as the NMW can play an important role in countering low pay in relation to groups such as migrants who may be subject to the monopsony wage setting powers of employers. The government's introduction of a National Living Wage (NLW) for those aged 25 and over,

together with its commitment to uprate the NLW to 60 percent of median earnings by 2020, may further limit opportunities for employers of migrant workers to pay low wages to sections of their workforce. Our research reinforces arguments for further regulatory intervention against low pay. 
${ }^{\mathrm{i}}$ Wadsworth (2015) Table 5 provides a breakdown of immigrant workers by industry. The Financial Times recently reported a call by the National Farmers' Union for a new seasonal agricultural worker scheme which would address labour shortages left by reductions in the number of migrant workers coming to the UK. These reductions, the NFU claimed, meant fruit was left rotting on trees (https://www.ft.com/content/13e183ee-c099-11e7-b8a3$38 \mathrm{a} 6 \mathrm{e} 068 \mathrm{f} 464)$.

${ }^{\text {ii }}$ A skill-based pay gap may persist between migrants and natives if some of those skills are unobserved in data.

iii This assumption regarding fixed short-run labour demand is likely to hold following the sluggish recovery of the British economy after the Great Recession (Amossé et al., 2016), which is the period we observe workplaces with and without migrant workers.

${ }^{\text {iv }}$ Few studies distinguish between taste-based and statistical discrimination (Guryan and Charles, 2013). In her correspondence test study for Germany Weichselbaumer (2016) shows employer call-back rates to Muslim women wearing headscarves are lower than the employer call-back rates to otherwise identical women, a finding which appears to be consistent with taste-based discrimination.

${ }^{\mathrm{v}}$ Our study - like most in the literature - is unable to address the general equilibrium effects that can arise through changes in aggregate labour supply.

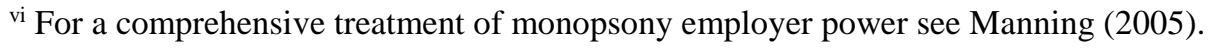

vii The importance of switching costs for the choice of employment regime is well-documented in other areas, such as employer choice of 'voice' regime (Willman et al., 2014).

viii For background information on types of migrant see CIPD (2013).

${ }^{\text {ix }}$ In that first report the LPC noted employers had begun to raise their wages in anticipation of the NMW (LPC, 1998: 131).

${ }^{\mathrm{x}}$ Results were robust to this alternative specification. Results are available on request. 


\section{References}

Alfano M, Dustmann C, and Frattini T (2016) Immigration and the UK: Reflections after Brexit. In: Fasani F (ed) Refugees and Economic Migrants: Facts, policies and challenges. London: CEPR Press, 55-80

Altonji J, Elder T, and Taber, C. (2005) Selection on Observed and Unobserved Variables: Assessing the Effectiveness of Catholic Schools. Journal of Political Economy 113(1): 151-184

Amossé T, Bryson, A and Petit H. (2016) How did Workplaces Respond to Recession? In:

Amossé T, Bryson, A., Forth J, and Petit H (eds) Comparative Workplace Employment Relations: An Analysis of Britain and France, Basingstoke: Palgrave Macmillan, 211-240

Angrist JD, and Pischke J-S (2009) Mostly Harmless Econometrics: An Empiricist's Companion Princeton, NJ: Princeton University Press.

Ashenfelter O, Farber H, and Ransom MR (2010) Modern Models of Monopsony in Labor Markets: A Brief Survey. IZA Discussion Paper No. 4915

Beck U. (2000) The Brave New World of Work Cambridge: Polity.

Benmelech, E., Bergman, N., and Kim, H. (2018) Strong Employers and Weak Employees: How Does Employer Concentration Affect Wages? NBER Working Paper 24307, Cambridge, MA: National Bureau of Economic Research

Berk RA (1990) A Primer on Robust Regression. In: Fox J and Long JS (eds.) Modern Methods of Data Analysis, Newbury Park, CA: Sage, 292-324

Bryson, A and Forth J. (2016) The UK's Productivity Puzzle. In: Askenazy P, Bellmann L, Bryson, A., and Moreno-Galbis E. (eds.) The Productivity Puzzle across Europe Oxford: Oxford University Press, 129-173

Castells M (2000) The Rise of the Network Society. 2nd. edn, Cambridge, MA: Blackwell. 
CIPD (2013) The State of Migration - Employing Migrant Workers Wimbledon: Chartered Institute of Personnel and Development.

Clark K. and Drinkwater S. (2008) The labour market performance of recent migrants Oxford Review of Economic Policy 24: 495-516

Dreher A, Gaston N, and Martens P (2008) Measuring Globalisation - Gauging its Consequences New York: Springer.

Dustmann, C, Fabbri F, and Preston I. (2005) The Impact of Immigration on the UK Labour

Market, The Economic Journal 115: F324-41

Dustmann, C, Glitz A. and Frattini T. (2008) The Labour Market Impact of Immigration Oxford Review of Economic Policy 24(3): 477-494

Dustmann C, Frattini T, and Preston, I. (2013) The Effect of Immigration along the Distribution of Wages Review of Economic Studies 80: 145-73

Dustmann C, and Frattini T. (2014) The Fiscal Effects of Immigration to the UK The Economic Journal 124: F593-643

Falk A, Fehr E, and Zehnder C. (2006) The behavioral effects of minimum wage laws The Quarterly Journal of Economics 121, 4: 1347-1381

Gangopadhay P, and Shankar S (2015) Labour (im)mobility and monopsonistic exploitation of workers in the urban informal sector: Lessons from a field study, Urban Studies, 53(2): 1042-60

Gilman M, Edwards P, Ram M, and Arrowsmith J. (2002) Pay determination in small firms in the UK: the case of the response to the National Minimum Wage Industrial Relations Journal $33,1: 52-67$

Goldthorpe JH (2007) On Sociology, Volume Two: Illustration and Retrospect. Stanford, CA: Stanford University Press. 
Guryan J, and Charles KK (2013) Taste-based or Statistical Discrimination: The Economics of Discrimination Returns to Its Roots The Economic Journal, 123, F417-F432

Hainmueller J, and Xu Y (2013) ebalance: A Stata Package for Entropy Balancing Journal of Statistical Software 54(7): 1-18

Imbens GW, and Wooldridge JM (2009) Recent developments in the econometrics of program evaluation Journal of Economic Literature 47(1): 5-86

Kalleberg AL (2011) Good Jobs, Bad Jobs: The Rise of Polarized and Precarious Employment Systems in the United States, 1970s to 2000s, New York: Russell Sage Foundation.

Kennedy P (2003) A Guide to Econometrics Cambridge, Mass: MIT Press

Kersley B, Alpin C, Forth J, Bryson, A., Bewley H, Dix G, and Oxenbridge S. (2006) Inside the Workplace: Findings from the 2004 Workplace Employment Relations Survey London: Routledge.

Low Pay Commission (1998) The National Minimum Wage: First Report of the Low Pay Commission cm 3976, London: Her Majesty's Stationery Office.

Manning A (2005) Monopsony in Motion: Imperfect Competition in Labour Markets, Princeton: Princeton University Press

Metcalf D (2007) Why has the British national minimum wage had little or no impact on employment?, CEP Discussion Paper No.781

Neumark D, Zhang J. and Ciccarella S. (2005) The Effects of Wal-Mart on Local Labour Markets, NBER Working Paper No. 11782

Ransom MR and Sims DP (2010) Estimating the Firm's Labor Supply Curve in a 'New Monopsony' Framework: Schoolteachers in Missouri Journal of Labor Economics, 28 (2), 331355

Robinson J (1933) The Economics of Imperfect Competition, London: Macmillan 
Ruhs M, and Vargas-Silva C (2014) The Labour Market Effects of Immigration Oxford: Migration Observatory Briefing University of Oxford

Schmid E (2016) The Gender Wage Gap in Switzerland over Time Swiss Journal of Sociology, 42(3):443-67

Treadway DC, Ferris GR, Hochwarter WA, Perrewé PL, Witt LA and Goodman JM (2005) The Role of Age in the Perception of Politics - Job Performance Relationship: A Three-Study Constructive Replication Journal of Applied Psychology 90(5) 872-81.

van Wanrooy B, Bewley H, Bryson, A., Forth J, Freeth S, Stokes L, and Wood S (2013) Employment Relations in the Shadow of Recession: Findings from the 2011 Workplace Employment Relations Study Basingstoke: Palgrave Macmillan

Wadsworth J (2015) Immigration and the UK labour market CEP Paper EA019

Wadsworth J, Dhingra S, Ottaviano G, and Van Reenen J (2016) Brexit and the Impact of Immigration on the UK CEP Brexit Analysis No. 5.

Weichselbaumer D (2016) Discrimination against female migrants wearing headscarves IZA Discussion Paper No. 10217

Willman P, Bryson, A. Gomez R, and Kretschmer T (2014) Employee voice and the transaction cost economics project. In: Wilkinson A, Donaghey J, Dundon T, and Freeman R. (eds) Handbook of Research on Employee Voice, 52-65, Cheltenham: Edward Elgar 
Table 1: Descriptive statistics for lower quartile wage (unweighted)

\begin{tabular}{|c|c|c|c|c|c|c|c|c|}
\hline \multicolumn{9}{|c|}{ Panel A: log hourly wage } \\
\hline \multicolumn{3}{|c|}{ Whole sample } & \multicolumn{3}{|c|}{ Older workplaces } & \multicolumn{3}{|c|}{ Newer workplaces } \\
\hline mean & s.d. & $\mathrm{N}$ & mean & s.d. & $\mathrm{N}$ & mean & s.d & $\mathrm{N}$ \\
\hline 2.21 & 0.336 & $2474^{\mathrm{a}}$ & 2.22 & 0.327 & 1738 & 2.17 & 0.353 & 736 \\
\hline \multicolumn{9}{|c|}{ Panel B: lower quartile wage distribution over pay bands (whole sample) } \\
\hline \multicolumn{2}{|c|}{ Pay bands $(£)^{\mathrm{b}}$} & $5.0-5.93$ & $5.94-7.50$ & $7.51-10$ & $10.01-13.0$ & $13.01-18$ & $18.01-30$ & All \\
\hline \multicolumn{2}{|c|}{ row $\%$} & 8.7 & 23.0 & 30.3 & 22.3 & 11.6 & 4.1 & 100 \\
\hline \multicolumn{2}{|l|}{$\mathrm{N}$} & 217 & 570 & 753 & 553 & 289 & 102 & 2484 \\
\hline
\end{tabular}

a: Ns in this row exclude 10 cases where information about age of workplace is absent.

b: The pay distribution bands are those specified in the management questionnaire. 
Table 2. Marginal mean probability (s.e.) of employing migrants, by workplace size, regional location, and industry

\begin{tabular}{|l|l|l|l|l|l|}
\hline (a) & size $^{\mathrm{a}}$ & $(\mathrm{b})$ region & & $(\mathrm{c})$ industry & \\
\hline 20 & $0.35(0.02)$ & North & $0.134(0.03)$ & Manufacturing & $0.255(0.05)$ \\
\hline 50 & $0.55(0.02)$ & Yorkshire & $0.185(0.04)$ & Utilities & $0.110(0.05)$ \\
\hline 100 & $0.69(0.03)$ & East & $0.254(0.06)$ & Construction & $0.176(0.06)$ \\
\hline 250 & $0.84(0.03)$ & East Anglia & $0.250(0.08)$ & Distribution & $0.275(0.04)$ \\
\hline 500 & $0.91(0.02)$ & London/SE & $0.412(0.03)$ & Hospitality & $0.523(0.05)$ \\
\hline 1000 & $0.95(0.02)$ & South West & $0.312(0.05)$ & Transport/communication & $0.229(0.06)$ \\
\hline 2000 & $0.98(0.01)$ & West & $0.242(0.05)$ & Financial services & $0.246(0.10)$ \\
\hline & & North-west & $0.206(0.03)$ & Business services & $0.275(0.04)$ \\
\hline & & Wales & $0.184(0.05)$ & Public administration & $0.093(0.03)$ \\
\hline & & Scotland & $0.234(0.04)$ & Education & $0.229(0.05)$ \\
\hline & & & & Health & $0.381(0.05)$ \\
\hline & & & & Other community & $0.245(0.04)$ \\
\hline
\end{tabular}

Notes. a: the sizes (number of employees) for these probabilities are selected from a continuous size distribution and are approximate. 
Table 3: Estimated effects of migrant employment on workplace log lower quartile wage

\begin{tabular}{|l|l|l|l|l|l|}
\hline Model 1, all workplaces, additive effects & $\mathrm{b}$ & s.e. & $\mathrm{t}$ & $\mathrm{N}$ & $\mathrm{R}$-sq \\
\hline Migrants & -0.045 & 0.018 & $2.56^{*}$ & 2113 & 0.675 \\
\hline Newer workplaces & 0.018 & 0.017 & 1.05 & & \\
\hline Model 2, all workplaces, interaction effects & & & & & \\
\hline Migrant, older workplace & -0.050 & 0.021 & $2.33^{*}$ & 2113 & 0.675 \\
\hline No migrants, older workplace & 0.008 & 0.031 & 0.24 & & \\
\hline No migrants, newer workplace & 0.018 & 0.035 & 0.52 & & \\
\hline Model 3, older workplaces only & & & & & \\
\hline Migrants & -0.061 & 0.023 & $2.71^{* *}$ & 1475 & 0.694 \\
\hline Model 4, newer workplaces only & & & & & \\
\hline Migrants & -0.003 & 0.018 & 0.17 & 638 & 0.708 \\
\hline
\end{tabular}

* significant at the 5 per cent level ** significant at the 1 per cent level. 
Appendix Table 1: Influence of workplace characteristics on migrant employment

\begin{tabular}{|c|c|c|c|c|c|c|}
\hline & \multicolumn{2}{|c|}{ (1) All workplaces } & \multicolumn{2}{|c|}{ (2) Older workplaces } & \multicolumn{2}{|c|}{ (3) Newer workplaces } \\
\hline & $\mathrm{b}$ & $|t|$ & $\mathrm{b}$ & $|t|$ & $\mathrm{b}$ & $|\mathrm{t}|$ \\
\hline union recognized & -0.428 & 1.64 & -0.081 & 0.24 & -0.489 & 1.07 \\
\hline$\%$ female employees & -0.006 & 1.55 & -0.007 & 1.35 & -0.005 & 0.76 \\
\hline$\%$ higher occupations & 0.008 & $1.81+$ & 0.001 & 0.21 & 0.018 & $2.31 *$ \\
\hline$\%$ intermediate occupations & -0.005 & 1.37 & -0.003 & 0.75 & -0.006 & 1.00 \\
\hline$\%$ non-permanent contracts & 0.002 & 0.78 & 0.005 & 0.98 & -0.0003 & 0.11 \\
\hline \multicolumn{7}{|l|}{ Region (ref: North) } \\
\hline Yorkshire & 0.532 & 1.11 & 0.060 & 0.10 & 1.71 & $1.81+$ \\
\hline East midlands & 0.962 & $1.82+$ & 1.523 & $2.30 *$ & 1.26 & 1.33 \\
\hline East Anglia & 1.13 & $1.72+$ & 1.453 & $1.87+$ & 1.34 & 1.16 \\
\hline South east and London & 1.939 & $4.79 * *$ & 1.284 & $2.74 * *$ & 3.39 & $3.95 * *$ \\
\hline South west & 1.396 & $2.88 * *$ & 1.337 & $2.36^{*}$ & 2.17 & $2.22 *$ \\
\hline West midlands & 0.836 & $1.68+$ & 0.407 & 0.74 & 2.09 & $2.01 *$ \\
\hline North west & 0.689 & 1.59 & 0.598 & 1.14 & 1.33 & 1.49 \\
\hline Wales & 0.602 & 1.08 & 0.496 & 0.75 & 1.08 & 0.99 \\
\hline Scotland & 1.019 & $2.24 *$ & 0.898 & $1.74+$ & 1.86 & $1.95+$ \\
\hline \multicolumn{7}{|c|}{ Multi-site Organization (ref.: single-site): } \\
\hline$<1000$ employees & 0.196 & 0.90 & 0.116 & 0.42 & 0.430 & 1.16 \\
\hline 1000-9999 employees & 0.627 & $1.99 *$ & 0.587 & 1.48 & 0.887 & $1.69+$ \\
\hline 10000-plus employees & 0.498 & 1.49 & 0.433 & 1.05 & 0.372 & 0.62 \\
\hline private sector & 0.641 & $1.94+$ & 0.699 & 1.61 & 1.703 & $2.57 *$ \\
\hline \multicolumn{7}{|l|}{ Industry (ref. manufacturing): } \\
\hline - utilities & -1.277 & $1.86+$ & -2.247 & $3.59 * *$ & -0.664 & 0.64 \\
\hline - construction & -0.602 & 1.00 & -1.208 & $1.87+$ & -0.381 & 0.39 \\
\hline - distribution & 0.225 & 0.63 & 0.501 & 1.16 & -0.210 & 0.32 \\
\hline - hospitality & 1.331 & $3.43 * *$ & 0.872 & $1.85+$ & 1.875 & $2.74 * *$ \\
\hline - transport/communications & -0.214 & 0.45 & -0.111 & 0.19 & -0.735 & 0.86 \\
\hline - finance & -0.145 & 0.19 & -1.290 & $1.87+$ & -0.263 & 0.24 \\
\hline - business services & 0.095 & 0.26 & 0.559 & 1.17 & -0.452 & 0.76 \\
\hline - public administration & -1.613 & $3.03 * *$ & -1.828 & $2.85 * *$ & -0.593 & 0.49 \\
\hline - education services & -0.399 & 0.86 & 0.059 & 0.10 & -1.801 & $-2.09 *$ \\
\hline - health services & 0.532 & 1.30 & 0.618 & 1.20 & 0.249 & 0.34 \\
\hline - community services & -0.020 & 0.05 & 0.184 & 0.36 & -0.648 & 0.74 \\
\hline newer (post-1997) workplace & 0.317 & 1.60 & --- & --- & --- & --- \\
\hline foreign ownership & 0.283 & 0.81 & 0.367 & 0.83 & 0.463 & 0.80 \\
\hline log employees at workplace & 1.083 & $11.11 * *$ & 0.919 & $8.04 * *$ & 1.514 & $8.22 * *$ \\
\hline constant & -6.057 & $8.01 * *$ & -5.329 & $6.16^{* *}$ & -9.059 & $6.23 * *$ \\
\hline $\mathrm{N}$ & 2119 & & 1476 & & 638 & \\
\hline Model F & 6.93 & & & & 4.26 & \\
\hline
\end{tabular}


Notes. Logit models with public use weights and robust variance estimation. Estimated coefficients are log-odds. Significance: + significant at the 10 per cent level, $*$ significant at the 5 per cent level, ${ }^{* *}$ significant at the 1 per cent level. 